\title{
Osteosarcoma with atypical location in an elderly female patient
}

\author{
Daniel Cury Ogata ${ }^{a}$, Rafael Saviolo Moreira ${ }^{b}$, Alberto Ramos Gomes ${ }^{c}$, \\ Elisiário Pereira Neto ${ }^{a}$, Daniel Oséias Sezerino ${ }^{a}$, Matsue Braga Hirano ${ }^{d}$
}

Ogata DC, Moreira RS, Gomes AR, Pereira Neto E, Sezerino DO, Hirano MB. Osteosarcoma with atypical location in an elderly female patient. Autopsy Case Rep [Internet]. 2011;1(4):45-49. http://dx.doi.org/10.4322/acr.2011.016

\section{ABSTRACT}

Osteosarcoma most frequently affects long bones, particularly around the knee, and is therefore rare in the forearm. We report the case of a 67-year-old woman presenting with progressive lesion of the distal radius. A pathological diagnosis of osteoblastic osteosarcoma was suspected and was confirmed by needle biopsy. There had been two other cases of osteosarcoma in the same family. The patient was treated with neoadjuvant chemotherapy followed by amputation of the arm below the elbow.

Keywords: Radius; Juxtacortical osteosarcoma; Amputation; Adjuvant chemotherapy; Chemotherapy.

\section{CASE REPORT}

A 67-year-old female patient noticed swelling in her distal radius, followed by local pain one month later. She had a family history of osteosarcoma (a daughter who had died from it and a nephew who was currently under treatment for it) but had no other risk factors for the disease. The patient initially underwent X-ray of the forearm. The X-ray showed lytic lesion of the distal radius, with irregular contours and heterogeneous areas of sclerosis in the adjacent bone marrow, together with periosteal alterations in the typical "sunburst" pattern (Figure 1).

On the basis of the X-ray findings and the family history, the working diagnosis was osteosarcoma. Subsequent magnetic resonance imaging (MRI) showed a bulky primary lesion of the distal radius. The lesion had a prominent soft tissue component with a locally aggressive aspect (Figure 2).

Based on these results, we chose to perform a needle biopsy, which revealed high-grade osteoblastic osteosarcoma. Additional imaging tests ruled out the possibility of metastatic disease at the time of diagnosis of the primary lesion. The Enneking stage was IIB.

The proposed treatment was neoadjuvant chemotherapy with doxorubicin and cisplatin. However, because the clinical response was

\footnotetext{
a Pathologist - Universidade do Vale do Itajaí - Balneário de Camboriú/SC - Brazil.

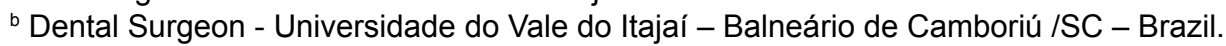

${ }^{c}$ Orthopedic Oncologist - Hospital Marieta Konder Bornhausen - Itajaí/SC - Brazil.

d Medical Student - Universidade do Vale do Itajaí - Balneário de Camboriú /SC - Brazil.
}

Copyright $\odot 2011$ Autopsy and Case Reports - This is an Open Access article distributed of terms of the Creative Commons Attribution NonCommercial License (http://creativecommons.org/licenses/by/3.0/) which permits unrestricted non-commercial use, distribution, and reproduction in any médium provided article is properly cited. 


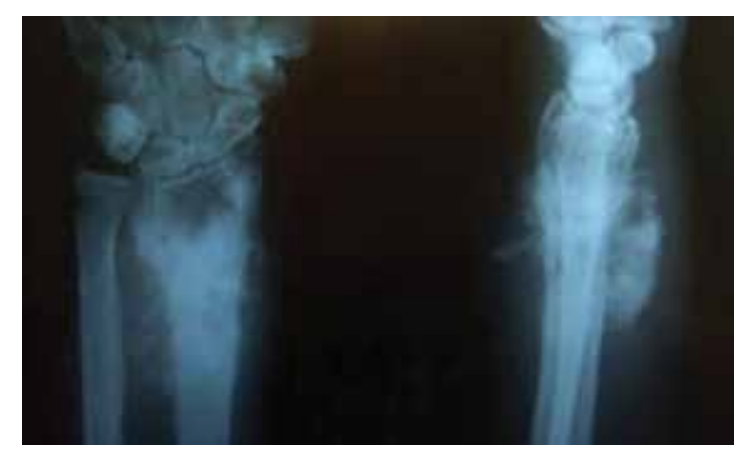

Figure 1 - X-ray of the forearm. Lytic lesion of the distal radius, with irregular contours and heterogeneous areas of sclerosis in the adjacent bone marrow, together with "sunburst" periosteal reaction.

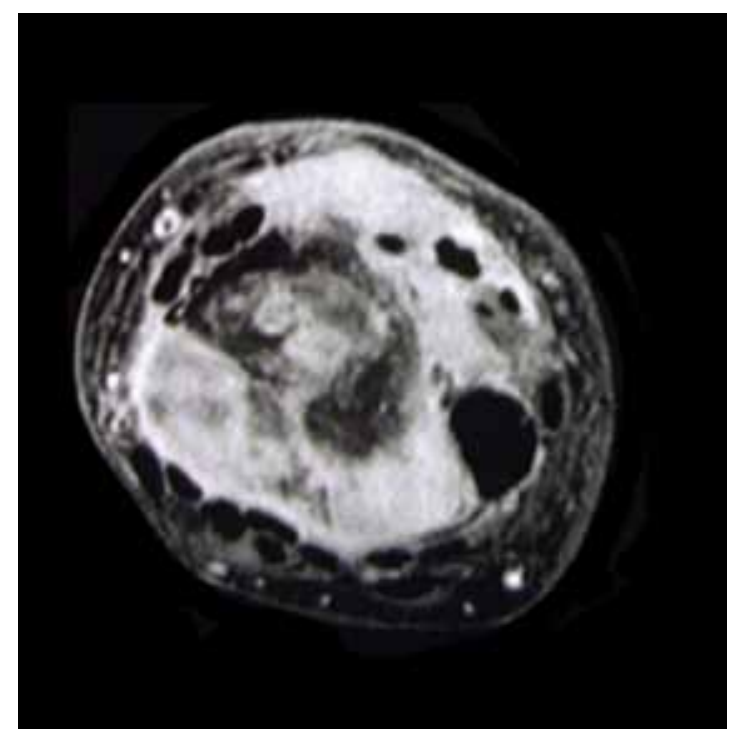

unsatisfactory, only three cycles were performed. The arm was then amputated below the elbow (Figure 3).

The pathological examination of the lesion again confirmed that it was high-grade osteoblastic osteosarcoma and showed minimal (Huvos grade 1) tumor necrosis (Figure 4).

The surgical margins were free of neoplasia. Currently, the patient began adjuvant chemotherapy, using the same initial regimen adding ifosfamide. At this writing, the patient was healthy, although the short follow-up period precluded a prognostic analysis.

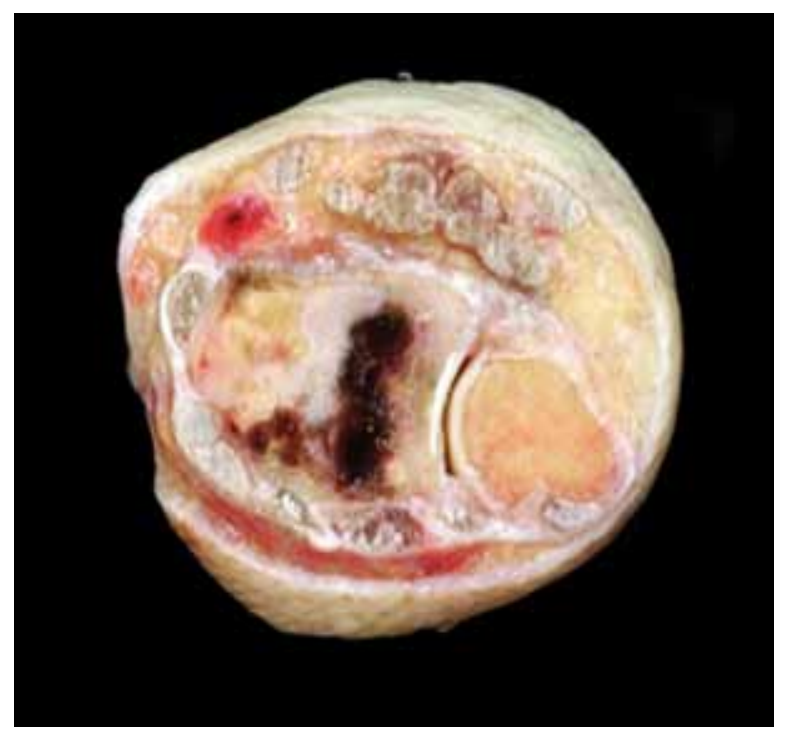

Figure 2 - Nuclear magnetic resonance imaging (left) and macroscopic view of the lesion in the longitudinal plane (right). Note large soft tissue component ventrally displacing the flexor tendons, with no clear planes between the lesion and the tendons. There are signs of invasion of various extensor muscles, together with involvement of the interosseous membrane and anterior interosseous artery.
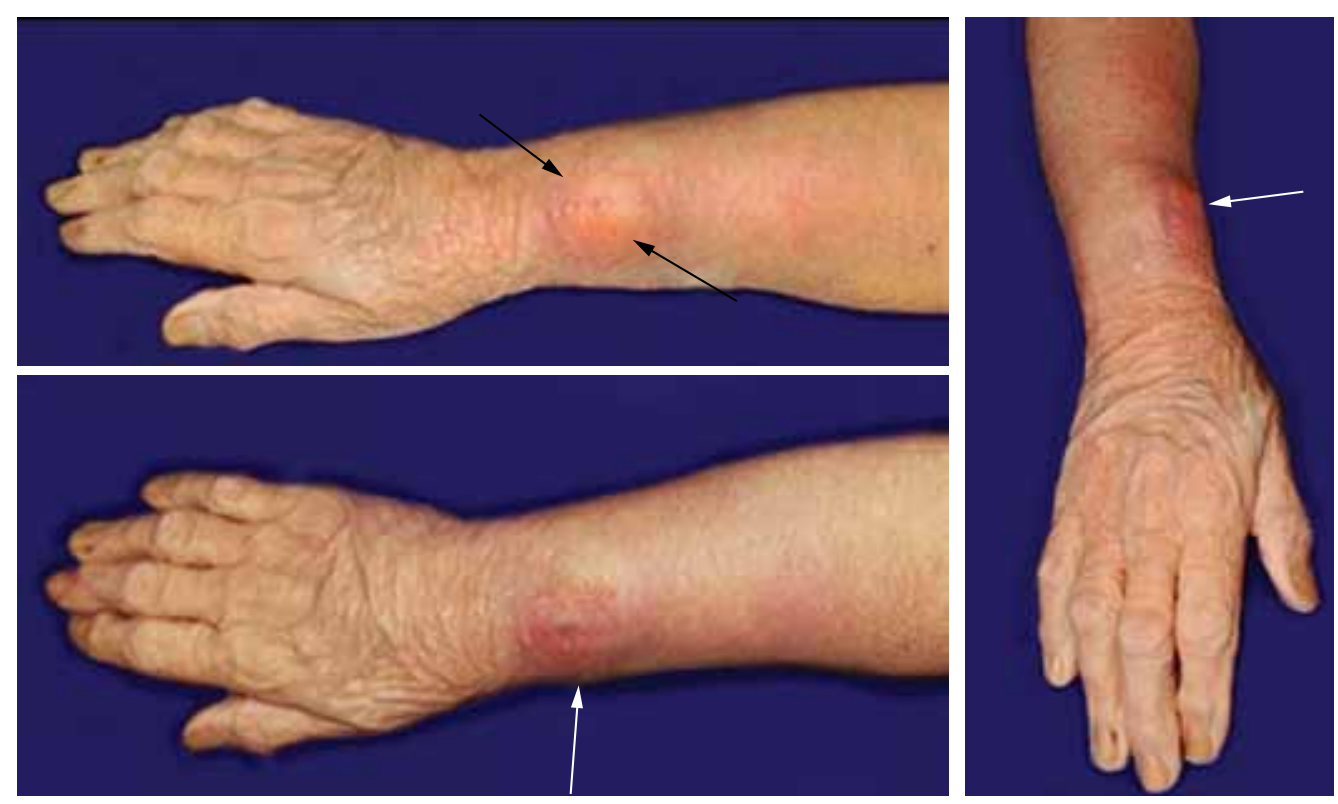

Figure 3 -Amputated arm showing a prominence in the region of the distal radius. 

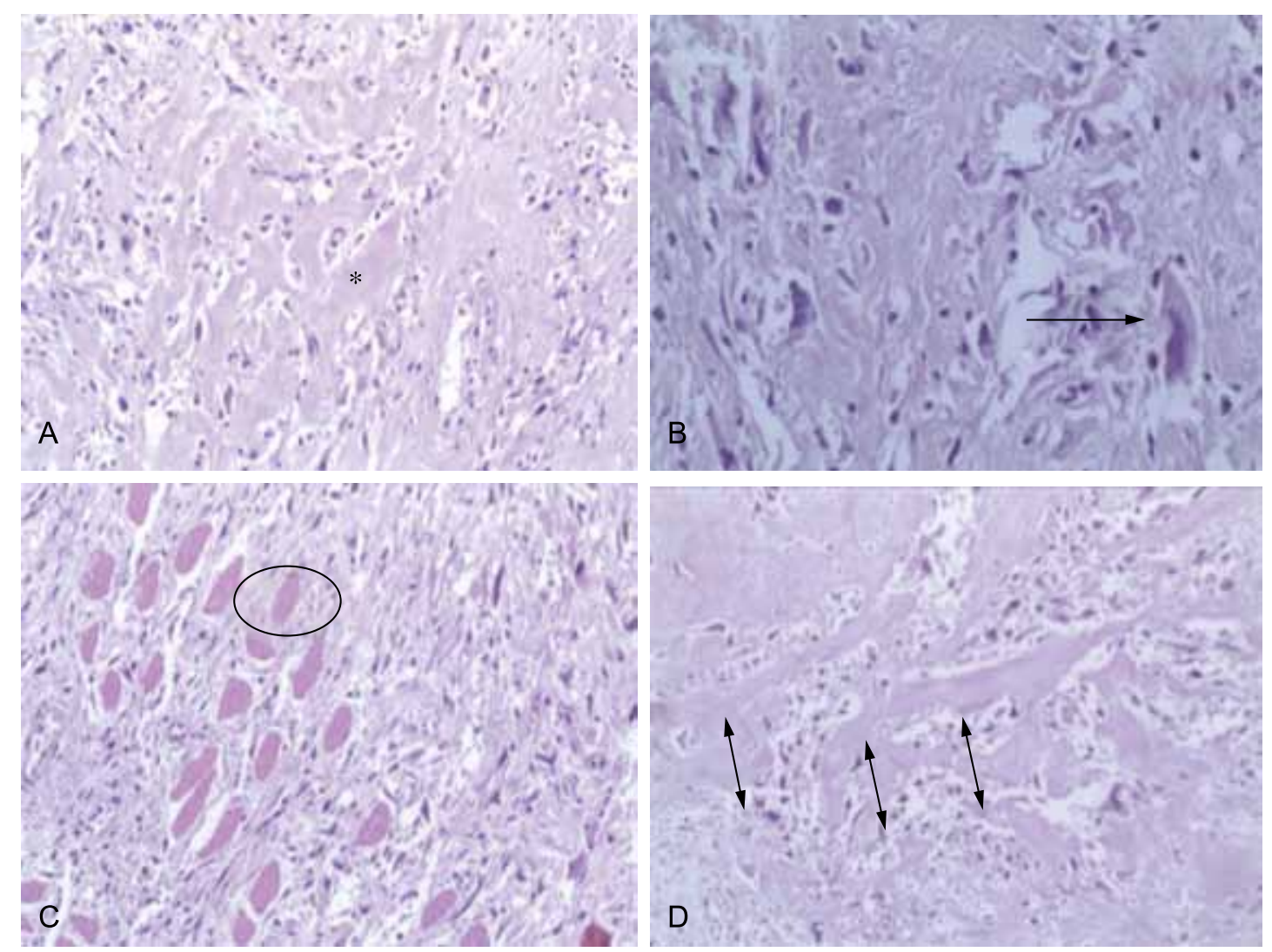

Figure 4 - Photomicrographs showing osteoid (asterisk, in A; hematoxylin and eosin [H\&E]; magnification, $\times 200$ ) produced by anaplastic cells (arrow, in B; H\&E; magnification, $\times 400$ ). The tumor infiltrates striated muscle tissue (ellipse, in C; H\&E; magnification, $\times 200$ ), and tumor necrosis is minimal (arrows, in D; H\&E; magnification, ×200).

\section{DISCUSSION}

Osteosarcoma is one of the most common types of primary malignant bone tumor, second only to multiple myeloma and lymphoma. ${ }^{1,2}$ Osteosarcoma of the forearm is extremely rare, ${ }^{1}$ accounting for approximately $4 \%$ of all cases, only about half of which involve the radius. ${ }^{2}$

Morphologically, osteosarcomas are defined as mesenchymal tumors whose malignant cells produce bone matrix in the form of osteoid or as immature bone. ${ }^{3}$ Although these tumors occur in all age groups, the age distribution is bimodal, $75 \%$ of cases occurring in individuals below 20 years of age. A smaller peak of incidence is observed in individuals in older age. In such cases, there is typically some predisposing condition, such as a history of irradiation, Paget's disease, and bone infarction. In the case reported here, a family history of osteosarcoma was the only predisposing factor. ${ }^{3}$ Considering the rarity of this type of neoplasm, the number of cases in which a family history of osteosarcoma has been reported is impressive. The study of the genetics of such tumors has made an important contribution to the understanding of cancer in general, one example being the identification of the retinoblastoma protein $(p R b)$, which plays a major role in cell cycle control. Another important gene is $p 53$, the product of which regulates DNA repair. Although the basic mechanisms of osteosarcoma development are unknown, defects in $\mathrm{pRb}$ and p53 clearly play an important role in this process. This association is evidenced by the rare patients with germline mutations in the $\mathrm{pRb}$ gene, as well as in those with Li-Fraumeni syndrome, which involves a germline mutation of the p53 gene. In such patients, the risk of developing osteosarcoma can be as much as 1,000 times higher than in those without such mutations. ${ }^{4}$

Osteosarcoma typically occurs in the metaphyses of long bones, the knee being affected in more than half of all cases. ${ }^{5}$ In adolescence, the occurrence of osteosarcoma seems to be related to the growth spurt of puberty, occurring in the regions of most active growth, probably due to osteoblast activity. ${ }^{4}$ These tumors grow circumferentially across the cortex, infiltrating soft tissue and, in rare cases, invading the intra-articular spaces. ${ }^{2}$

Histologically, osteosarcomas are divided into three subgroups, in accordance with the proportion 
of bone matrix produced: predominantly osteoblastic osteosarcoma; predominantly chondroblastic osteosarcomas; and predominantly fibroblastic osteosarcomas. The histological type is defined on the basis of the predominance of more than $50 \%$ of one of the matrices. ${ }^{3}$ This subdivision seems to be of no prognostic importance, given that there is no significant difference in survival among patients with high-grade osteosarcoma, regardless of the subtype. The neoplastic cells of osteosarcomas vary from spindle-shaped to polyhedral cells, their nuclei being pleomorphic and hyperchromatic. Mitotic figures are easily seen, and atypical forms are readily identified. ${ }^{3}$ Production of bone or osteoid by tumor cells is essential for the definitive diagnosis. ${ }^{1}$ Other, unusual, histological types of osteosarcoma include giant cell-rich osteosarcoma, ${ }^{6}$ and epithelioid osteosarcoma, ${ }^{7}$ as well as small cell osteosarcoma and osteoblastoma-like osteosarcoma. ${ }^{8}$

Another important point involving histology is the degree of primary tumor necrosis after preoperative chemotherapy, which has been considered one of the most important prognostic factors. ${ }^{9} \mathrm{~A}$ tumor showing more than $90 \%$ necrosis, for instance, tends to have a favorable prognosis, whereas those showing little or no necrosis, as occurred in the case reported here, usually have a poor prognosis. ${ }^{2,9}$

Radiological findings include tubular bone metaphyseal location, mixed pattern of osteolysis and osteosclerosis, cortical destruction, periostitis, and soft tissue mass. ${ }^{1}$ Purely lytic lesions are uncommon, occurring in only $10 \%$ of cases. In such cases, the differential diagnosis should include nonosteoid producing lesions, such as malignant fibrous histiocytoma, fibrosarcoma, metastatic disease, and Ewing's sarcoma. Special osteosarcoma subtypes, producing little osteoid, should also be included. ${ }^{1}$ Computed tomography and nuclear MRI are useful for demonstrating soft tissue invasion, which is common in osteosarcomas. Nuclear MRI can also be useful for showing discrete, "punched-out" lesions in the bone marrow. ${ }^{2}$

High-dose neoadjuvant chemotherapy is the most widely recommended form of treatment, ${ }^{2}$ the objective of which is to increase the chances of saving the affected limb. ${ }^{5}$ Neoadjuvant chemotherapy plays an important role in tumor growth inhibition, allowing increasingly conservative resections. ${ }^{10}$ Doxorubicin, cisplatin, high-dose methotrexate with leucovorin rescue, and ifosfamide are currently considered the most effective agents against osteosarcomas. ${ }^{11}$ However, the ideal combination has yet to be defined. ${ }^{11}$ At certain health facilities, ifosfamidecyclophosphamide-doxorubicin cycles are used. ${ }^{12}$ The lesion must then be surgically removed, with wide resection margins. ${ }^{12}$ Bielack et al. ${ }^{10}$ noted that the overall mean survival was higher for patients with wide resection margins than for those with narrower resection margins. Unfortunately, the patient described here did not respond well to the neoadjuvant chemotherapy. This might be directly related to the initial chemotherapy regimen. Because there is no consensus regarding the best combination of drugs for the treatment of osteosarcomas, various protocols are currently used. Therefore, it is possible to suppose that a different regimen might have yielded better results.

The prognosis depends on numerous variables, including tumor size, histological type, metastases, cytogenetic changes, age, sex, and response to neoadjuvant chemotherapy. ${ }^{13}$ The location of the tumor has been an important prognostic factor. Greater proximity of osteosarcoma to the trunk is usually associated with lower survival. ${ }^{4}$ Daecke et al. ${ }^{5}$ found that the overall survival rates for cases of osteosarcoma of the hands and forearms were higher than was the mean survival rate for all cases of osteosarcoma.

We reported the case of an elderly female patient with osteosarcoma of the distal radius. Although the patient had no history of bone disease or irradiation, she did have a family history of osteosarcoma. Although the short follow-up period precluded a prognostic analysis, there was no evidence of recurrence or metastatic disease at this writing.

\section{REFERENCES}

1. Joo I, Choi JA, Chung JH, Oh JH, Hong SH and Kang HS. Fibroblastic type osteosarcoma of the ulna: a Case Report of a tumor in a rare location with atypical imaging findings. Korean J Radiol. 2009; 10(1):85-8. PMid:19182508. PMCid:2647176. http://dx.doi.org/10.3348/kjr.2009.10.1.85

2. Vigorita VJ. Bone tumors. In: Vigorita VJ, editor. Orthopaedic pathology. Philadelphia: Lippincott Williams and Wilkins; 2008. p. 338-79.

3. Klein MJ, Siegal GP. Osteosarcoma: anatomic and histologic variants. Am J Clin Pathol. 2006; 125(4):55581. PMid:16627266. http://dx.doi.org/10.1309/ UC6KQHLD9LV2KENN 
4. Kansara M, Thomas DM. Molecular pathogenesis of osteosarcoma. DNA Cell Biol. 2007;26(1):1-18. PMid:17263592. http://dx.doi.org/10.1089/dna.2006.0505

5. Daecke W, Bielack S, Martini AK, et al. Osteosarcoma of the hand and forearm: Experience of the cooperative osteosarcoma study group. Ann Surg Oncol. 2005;12(4):32231. PMid:15827675. http://dx.doi.org/10.1245/ ASO.2005.06.002

6. Fu HH, Zhuang QW, He J, Huang LZ, He Y. Giant cellrich osteosarcoma or giant cell reparative granuloma of the mandibule? J Craniofac Surg. 2011;22(3):11369. PMid:21586969. http://dx.doi.org/10.1097/ SCS.0b013e3182108fbf

7. Kaveri H, Rekha K, Punnya VA. Epithelioid osteosarcoma of the maxilla: report of an unusual case. $\mathrm{Br} \mathrm{J}$ Oral Maxillofac Surg. 2009;47(2):143-5. PMid:18762359. http://dx.doi. org/10.1016/j.bjoms.2008.07.188

8. Andrade Filho JS, Pena GP, Aymoré IL. Sistema osteoarticular. In: Brasileiro Filho G, editor. Bogliolo patologia. 8. ed. Rio de Janeiro: Guanabara Koogan; 2011: p. 1049-52. Portuguese.

\section{Conflict of interest: None}

Submitted on: $12^{\text {nd }}$ September 2011

Accept on: $10^{\text {th }}$ October 2011

\section{Correspondence:}

Prof. Dr. Daniel Cury Ogata

Rua Jacob Schimdt, 102/304 - Bairro Pioneiros

Balneário Camboriú/SC - Brazil

CEP: 88331-015

E-mail: daniel.ogata@gmail.com
9. Huvos AG, Rosen G, Marcove RC. Primary osteogenic sarcoma: pathologic aspects in 20 patients after treatment with chemotherapy, en bloc resection, and prosthetic bone replacement. Arch Pathol Lab Med. 1977;101(1):14-8. PMid:299812.

10. Bielack S, Kempf-Bielack B, Delling G, et al. Prognostic factors in high grade osteosarcoma of the extremities or trunk. An analysis of 1702 patients treated on cooperative osteosarcoma study group protocols. J Clin Oncol. 2002;20(3):776-90. PMid:11821461. http://dx.doi.org/10.1200/JCO.20.3.776

11. Ritter J, Bielack SS. Osteosarcoma. Ann Oncol. 2010;21(7):320-5. PMid:20943636. http://dx.doi. org/10.1093/annonc/mdq276

12. Cassone AE, Barbe-Gonçalves JC, Silva AAM, Epelman $\mathrm{S}$, Amstaldem EMI. Tratamento multi-disciplinar do osteossarcoma. Rev Bras Ortop. 1998:33(11):835-40. Portuguese.

13. Castro HC, Ribeiro KCB, Bruniera P. Osteossarcoma: experiência do Serviço de Oncologia Pediátrica da Santa Casa de Misericórdia de São Paulo. Rev Bras Ortop [Internet]. 2008;43(4):108-15. Portuguese. 